\title{
Subjective well-being among the self-employed in Europe: macroeconomy, gender and immigrant status
}

\author{
Ingemar Johansson Sevä • Stig Vinberg • \\ Mikael Nordenmark • Mattias Strandh
}

Accepted: 28 September 2015/Published online: 13 October 2015

(C) Springer Science+Business Media New York 2015

\begin{abstract}
Previous research shows that the selfemployed generally experience a higher degree of job satisfaction compared to regular employees. However, our knowledge of subjective well-being among the self-employed, the differences between various groups of self-employed and the potential influence of contextual factors is somewhat limited. The purpose of the present paper is to address this gap by taking macroeconomic conditions, gender and immigrant status into consideration. The results show that selfemployment is positively related to subjective well-
\end{abstract}

I. Johansson Sevä $(\bowtie) \cdot$ M. Strandh

Department of Sociology, Umeå University, Umeå,

Sweden

e-mail: ingemar.johansson.seva@soc.umu.se

M. Strandh

e-mail: mattias.strandh@socw.umu.se

S. Vinberg $\cdot$ M. Nordenmark

Department of Health Sciences, Mid Sweden University,

Östersund, Sweden

e-mail: Stig.Vinberg@miun.se

M. Nordenmark

e-mail: Mikael.Nordenmark@miun.se

\section{Strandh}

Department of Social Work, Umeå University, Umeå, Sweden

\section{Strandh}

Centre for Research on Child and Adolescent Mental

Health, Karlstad University, Karlstad, Sweden being, but there are also differences between groups of the self-employed; self-employed with employees report a higher level of life satisfaction than the selfemployed without employees. Economic growth is more important for the level of life satisfaction among the self-employed than among employees. The analyses also point to different patterns for female and male self-employed without employees: only women experience a higher level of life satisfaction compared to employees. The results also show that the relationship is stronger among immigrants than natives. The results of this study confirm the importance of considering potential heterogeneity when examining subjective well-being among the self-employed.

Keywords Self-employment - Subjective wellbeing - Life satisfaction - Economic growth · Immigrant status $\cdot$ Gender $\cdot$ Europe

JEL Classifications $\quad \mathrm{I} 31 \cdot \mathrm{J} 23 \cdot \mathrm{L} 26$

\section{Introduction}

Entrepreneurship and self-employment have long been regarded as of central importance for the economy and job creation (Davidsson 2005; Fölster 2000; Henrekson and Stenkula 2009). The macroeconomic importance of self-employment has been coupled with political initiatives that point to the advantages of self-employment for individuals, such 
as high levels of decision-making authority, work flexibility and skills development (European Commission 2004; Verheul and Wennekers 2002). These positive aspects of self-employment have also been empirically supported by various studies which show that despite experiencing longer working hours and heavier demands than regular employees, the selfemployed generally experience richer working lives and have higher measures of self-determination, freedom and autonomy (Eden 1975; Nordenmark et al. 2012; Stephan \& Roesler 2010).

In contrast to the abundance of literature on the positive aspects of self-employment in terms of working life itself, comparatively little research has been done on the consequences and outcomes of selfemployment in terms of personal well-being and health (Dolinsky and Caputo 2003). There are a large number of studies on the subjective well-being of salaried employees, but few researchers have looked at the self-employed from this perspective (Andersson 2008; Hilbrecht and Lero 2014; Stephan and Roesler 2010). Of the studies that have been done, most have generally found a positive relationship between selfemployment and subjective well-being (Blanchflower 2004; Benz and Frey 2008; Andersson 2008), but some also point to notable differences in subjective well-being among the self-employed, and link these differences to the variety of reasons for becoming selfemployed that exist (Binder and Coad 2013). No differences or even recorded worse subjective wellbeing among groups of the self-employed have also been found in some studies (Jamal 1997; Parslow et al. 2004; Gunnarsson et al. 2007).

Research suggests that there is a marked degree of heterogeneity among the self-employed in terms of personal characteristics, motivations and working conditions (Aldrich and Renzulli 1981; Fuchs-Schundeln 2009). This raises questions about who benefits from self-employment, and the nature of particular conditions under which self-employment is beneficial for subjective well-being. There are substantial differences in work conditions between the self-employed and the comparison group of salaried employees, but there is good reason to believe that these conditions also vary within the group of selfemployed as a whole. As has been pointed out (Toivanen et al. 2014), there is a need to differentiate between various legal forms of enterprise as well as between the self-employed with and without employees; there is also a need to differentiate within the comparison group of employees whose conditions of work differ substantially depending on whether they are supervisors or not. Furthermore, self-employment intersects with gender and immigrant status, meaning that both the purposes and preconditions of different self-employed groups may vary. Questions about the conditions under which self-employment is beneficial for subjective well-being are, however, not only related to individual- and organizational-level factors-they could also be related to macroeconomic factors; essentially, is self-employment equally beneficial during different stages of the business cycle?

This article aims to investigate the benefits of selfemployment for subjective well-being among the selfemployed both with and without employees, as well as examining whether macroeconomic conditions, gender and immigrant status are significant factors affecting the relationship between self-employment and subjective well-being. Four research questions are investigated: (1) do self-employed individuals experience a higher or a lower level of life satisfaction than that experienced by employees and supervisors? (2) Are there differences between the self-employed with and without employees regarding their levels of life satisfaction? (3) Are macroeconomic conditions more or less important for the life satisfaction of selfemployed people compared with supervisors and employees? (4) Does the relationship between employment type and life satisfaction vary according to gender and immigrant status? The first two questions have been investigated previously and are here asked mainly in order to replicate previous studies by using a broad sample of European countries and also in order to provide a baseline for the subsequent analyses. Question three and four have received considerably less attention in previous research and thus constitute the main contribution of this article. In order to answer these questions, this article uses multilevel modelling and data drawn from the first five waves $(2002,2004$, 2006, 2008 and 2010) of the European Social Survey (ESS), as well as macroeconomic indicators of economic conditions within each country taken from the Organization for Economic Co-operation and Development (OECD). This allows for the analysis of, not only, national context but also the development of national context over time. This has to our knowledge not been done previously regarding the relationship between employment type and subjective well-being. 


\section{Earlier research}

Since the 1990s subjective well-being (SWB) has been the object of considerable research interest, and it is now regarded as a central element in an individual's life. The significance of SWB for individuals, as well as for society, is widely recognized (Diener and Seligman 2004; Veenhoven 2004; Jovanovic 2011). SWB has, for example, been found to be associated with a wide variety of positive outcomes such as good health and work performance (Diener 2000; Diener et al. 1999; Weiss et al. 2008). The most frequently used definition of the concept defines SWB as a construct divided into three components. Firstly, SWB includes a global cognitive evaluation of an individual's life which can be labelled life satisfaction; secondly, SWB includes positive affect - the experience of pleasant emotions-and thirdly, the absence of negative affect (Diener 1984). In this article, the focus is on the first, cognitive component of SWB, i.e. life satisfaction.

\subsection{Self-employment and SWB}

Despite the increasing interest in research on the selfemployed and SWB in general, relatively little work has brought the two together and focused on the SWB of the self-employed. The more narrow concept of job satisfaction and its relationship with self-employment has on the other hand received a lot of scholarly interest, and findings generally show that self-employment is associated with a higher degree of job satisfaction than regular employment (Benz and Frey 2004; Blanchflower 2004; Lange 2012). Given the pronounced differences in their working conditions, there are good reasons to expect differences also in SWB between the self-employed and employees. Previous research has shown that self-employed individuals experience more flexibility in their working lives and find their jobs more satisfying (Loscocco and Roschelle 1991). The self-employed have less need to coordinate with work routines and coworkers, and have higher task autonomy and task variety (Hackman and Oldham 1975; Hundley 2001). An additional positive aspect might be the greater ability to control their work-life in order to meet threats and opportunities in the marketplace (Hundley 2001). Even though it might be hard to determine the causal direction between working conditions and well-being, findings presented by Coad and Binder (2014) indicate that there is indeed a causal relationship between autonomy and subjective well-being.

On the negative side, research findings indicate that self-employment is connected with factors that could be related to lower SWB. The self-employed might suffer a greater risk of job insecurity given their dependence on fluctuating markets (Mandel 1996). Studies also show that they work longer hours and have less free time and more responsibility for their own jobs and incomes, and sometimes for those of their employees. Consequently, the self-employed generally experience significantly lower levels of work-life balance as compared to employees (Johansson and Öun 2015; Nordenmark et al. 2012).

Despite the foregoing, the empirical findings on the relationship between self-employment and SWB do suggest that the positive aspects of self-employment are largely predominant and that the self-employed in general report a higher SWB than employees. Blanchflower and Oswald (1998), using survey-based data from the USA, the UK and Germany, find that the selfemployed are more satisfied with their jobs and their lives than wage earners. Similarly, Blanchflower (2004) finds a positive correlation between being an entrepreneur and life satisfaction, although the correlation does not appear to be particularly strong. In a Swedish study, Andersson (2008) found that transitions from regular employment to self-employment are connected with higher life satisfaction. Binder and Coad (2013) similarly find a relationship where individuals who move from regular employment to self-employment experience an increase in life satisfaction, although individuals moving from unemployment to self-employment (necessity self-employed) are not more satisfied than their counterparts moving from unemployment to regular employment.

Some results, however, show that the self-employed have worse health-related outcomes than employees (Gunnarsson et al. 2007; Jamal 1997; Parslow et al. 2004; Rau et al. 2008). Parslow et al. (2004) find in an Australian study that self-employment is associated with relatively few mental health benefits, and Nordenmark et al. (2012) find no significant relationship between employment type and SWB. However, when controlling for the level of job control, the relationship between self-employment and well-being is significantly negative. This 
indicates that when comparing the self-employed and employees with the same level of job control, the selfemployed have a lower level of well-being than employees.

\subsection{Diversity in the conditions of the self- employed}

As shown above, there is evidence from previous research that indicates a positive relationship between self-employment and SWB, although there has been some variation in the findings. One reason for this variation is that previous research tended to treat the self-employed as a homogenous group, generally sharing similar rationale and working conditions. More recent work on self-employment has increasingly pointed towards a great diversity in terms of working conditions and the reasons for becoming selfemployed in contemporary society (Binder and Coad 2013; Block and Koellinger 2009; Müller and Arum 2004). There is thus substantial variation in conditions between different groups of self-employed and selfemployment intersects with gender and immigrant status meaning that both the purposes and preconditions of different self-employed may vary. One form of diversity of conditions that has received very little attention is macroeconomic circumstances, and the relationship between self-employment and subjective well-being under different macroeconomic conditions. With increasing macroeconomic instability, the conditions under which an individual is selfemployed also vary over time. Given this, it is important to investigate whether the relationship between self-employment and SWB is affected by both the personal characteristics of the self-employed individual and the economic business cycle.

We do know from previous research that there is a relationship between macroeconomic conditions and subjective well-being. Recession and poor labour market conditions have been found to be connected with poorer subjective well-being in the general population (Ochsen 2011; Tella et al. 2003; Welsch and Bonn 2008). There are good reasons to assume that the macroeconomy might affect the conditions of selfemployment in particular, and thus potentially the wellbeing of self-employed individuals. The self-employed have a more direct relationship with the market than regular employees; this is something that might have implications for experiencing job security. According to
Mandel (1996), for example, entrepreneurs should suffer greater risk of job insecurity and therefore experience lower levels of job satisfaction. Hundley (2001), on the other hand, found that entrepreneurs are less likely to be burdened by job insecurity. Instead, they tend to feel more secure due to their ability to control their work-life, deal with economic threats and take advantage of opportunities to secure the survival of their company and work. It is plausible to assume that controlling these factors is easier in a growing economy than in a recession and economic downturn. Therefore, it is also reasonable to believe that the responsibility for their own jobs and incomes (and for the jobs and incomes of their employees, if they have them) means that it is easier to be satisfied and happy when economic conditions are good. This reasoning is in line with results from the global entrepreneurship monitoring (GEM) report (Amoros and Bosma 2013) which show differences in subjective well-being according to the phase of the economic cycle in the countries under study. We may add that owner-managers in established firms tend to rate their level of subjective well-being higher than early-stage entrepreneurs, who may have to deal with more uncertainty and pressure in growing and sustaining a young business.

Diverse conditions of self-employment might also occur at the individual level. Research indicates that significant differences exist between female and male self-employed, the self-employed with and without employees, and between native and immigrant selfemployed individuals.

Some characteristics typically associated with selfemployment, such as long working hours, might have a negative influence on work-life balance. This might particularly be the case for women, who often carry the main responsibility of maintaining the household and childcare even though they work full time (Parasuraman and Simmers 2001). As many women increasingly set up their own businesses, the challenge of balancing work and family demands can become a critical issue. In a study of self-employed working conditions and health, it emerged that women reported higher psychological demands and intellectual discretion than did other professional groups (Bernin 2002). The study also showed that self-employed females have coping behaviours that might increase the risk of illness and that they encountered greater difficulties in relaxing outside of work when compared to male managers. This result corresponds with the results of 
other research that indicate that many self-employed women identify the stress of balancing work and family and the inter-role conflict that this creates as one of their biggest problems (Harte 1996).

However, women can also be attracted to the potential benefits of self-employment, including a perceived increase in flexibility and a greater ability to balance the rewards and demands of career and family (Rogers 1998). Although the reasons for choosing selfemployment vary, they often seem to be linked to gender role expectations. Men more often than women cite work-related reasons for becoming self-employed (Dawson et al. 2009; Marler and Moen 2005), and fathers are less likely than mothers to report family as a reason to choose self-employment. Rather, they emphasize employment opportunities, job control and high job satisfaction for choosing self-employment (Hilbrecht and Lero 2014). The fact that women more often than men report family commitments and less often financial gain as reasons to become selfemployed indicates that self-employment might be linked to broader quality of life terms among women than among men (Dawson et al. 2009). Statistics also show that a larger proportion of self-employed women are sole proprietors without employees as compared to men (Nordenmark et al. 2012). There is thus reason to believe that the positive relationship between selfemployment and overall life satisfaction will be stronger among women than among men, given that women typically carry the main responsibility for household and children and more often than men report family concerns as a reason for entering selfemployment. This would particularly hold for selfemployed women without employees.

Having employees or not is also in itself related to the conditions of self-employment. Most self-employed individuals are sole proprietors $(61 \%)$, and only around $10 \%$ have more than five employees. A sole proprietor is personally responsible for all of his or her financial transactions, and in cases of bankruptcy, they are also personally liable for any debts that may have accrued (Toivanen et al. 2014). It is possible that having employees influences stress levels and different health-related outcomes. In a recent Swedish study, mortality was $8-16 \%$ higher in sole proprietorship than in limited partnerships (Toivanen et al. 2014). Benavides et al. (2000) also found in a European study that the self-employed without employees reported higher percentages of job dissatisfaction, fatigue and muscular pains than the self-employed employing between one and nine persons (Benavides et al. 2000).

A final factor which could be related to the conditions of self-employment is immigrant status. When it comes to studies of self-employment among immigrants, high self-employment rates have been documented, and immigrants are known to be overrepresented in the self-employment sector compared to natives in many countries today. Factors such as the ethnocultural milieu, home country traditions, tax evasion, as well as unemployment and discrimination, have been found to influence the decision to become self-employed among the immigrant population in different countries (Andersson and Hammarstedt 2012; Dana 1997; Irastorza and Peña 2014; Ndofor and Priem 2011). Many of these factors suggest that there might be a higher proportion of necessity selfemployed among immigrants than among natives, which in turn could affect levels of subjective wellbeing. Given that necessity self-employment has been shown to be associated with lower levels of job satisfaction (Block and Koellinger 2009) as well as overall life satisfaction (Binder and Coad 2013), and that immigrant and minority groups often encounter circumstances such as marginality and discrimination in their host societies pushing them to become selfemployed in lack of better options, i.e. necessity selfemployment (Dana 1997), there is reason to assume that the benefits of self-employment in terms of subjective well-being are less salient among immigrants than among native-born individuals. However, previous research also highlights some factors which might point to the opposite relationship. Since immigrants might come from very diverse ethnocultural milieus in terms of entrepreneurial culture (Dana 1997), and since self-employment might represent a feasible way to become integrated in society, there is also reason to believe that the positive relationship between self-employment and subjective well-being holds for many immigrants.

In summary, research indicates that substantial differences exist in conditions between the selfemployed and employees, but also within the group of self-employed as a whole. These differences stem from macroeconomic circumstances, work organization, motivation and life situation-all of these factors could well influence levels of subjective well-being. There is, therefore, a need for more detailed studies of 
subjective well-being levels under different macroeconomic circumstances as well as among different groups of self-employed-sole proprietor and employer, male and female, native and immigrant.

\section{Data and variables}

The data used for the analyses are derived from the first five waves (2002, 2004, 2006, 2008 and 2010) of the European Social Survey (ESS). ESS is a comparative interview survey conducted biannually which currently has over 30 participating countries. In order to enhance comparability across countries, ESS has very thorough procedures for questionnaire construction, sampling and interviewing. All ESS sampling is based on nationally representative samples of residents aged 15 and over, and interviews are conducted face to face (for response rates in individual countries, methodology and further general information on ESS, see http:// www.europeansocialsurvey.org). For this study, we use data from all of the countries which participated in at least three of the first five ESS waves, and for which reliable macroeconomic indicators are available. This resulted in a final sample comprising 21 countries (listed in Table 1). The sample is restricted to include only individuals aged 16-64 years active in the labour market at the time of the survey, and the total sample consists of 148,243 respondents. The variables used in the subsequent analyses are described below.

\subsection{Dependent variable}

In order to measure the cognitive component of SWB across all waves of the ESS, we use 'life satisfaction', measured with the question, 'All things considered, how satisfied are you with your life as a whole nowadays?' which is available in the core module of ESS. The response scale consists of an 11-point rating scale $(0=$ extremely dissatisfied and $10=$ extremely satisfied). The mean value in the total sample is 7.04 (standard deviation $=2.18$ ).

\subsection{Independent variables}

The central independent variable-'employment type'-consists of the following four categories: 'self-employed with employees', 'self-employed without employees', 'supervisors' and 'employees'.
We thus distinguish between two categories of the self-employed based on whether they have employees or not. The other two independent variables of main interest are gender and immigrant status. To capture whether respondents are natives or immigrants, we use a variable labelled 'immigrant status' which divides respondents into three categories: 'natives', 'secondgeneration immigrants' and 'immigrants'.

\subsection{Contextual-level variables}

Our central contextual-level variables measure the state of the economy in each country. These macroeconomic variables are derived from information collected from the OECD database. The first variable, 'GDP per capita', is measured as the mean GDP per capita in thousand US dollars (derived from purchasing power parity calculations) over the time period 2002-2010, i.e. the time period covered by the ESS data. This variable is measured at the country level and provides an indication of the economic development of each country. The descriptive statistics presented in Table 1 show that 'GDP per capita' ranges from 14.7 (Poland) to 47.2 (Norway). The second contextuallevel variable, 'GDP growth', measures the yearly change (per cent) in GDP per capita and is thus measured at the country-year level. Table 1 provides the mean yearly change in each country as well as the minimum and maximum values. A covariate controlling for the ESS wave is also included in each model in order to control for any common trend over time in levels of life satisfaction.

\subsection{Individual-level confounders}

Two individual-level confounders-age and educational attainment - are included in the models. Previous research has demonstrated that these variables are related to life satisfaction as well as to type of employment (Eurofound 2012), which suggests that they need to be taken into account. Age is measured in four categories: '16-24 years', '25-39 years', '40-54 years' and '55-64 years'. Educational attainment is measured in five categories based on the International Standard Classification of Education (ISCED). ISCED is based on uniform and internationally agreed definitions of education statistics which facilitate cross-country comparisons of educational attainment. The lowest educational attainment 


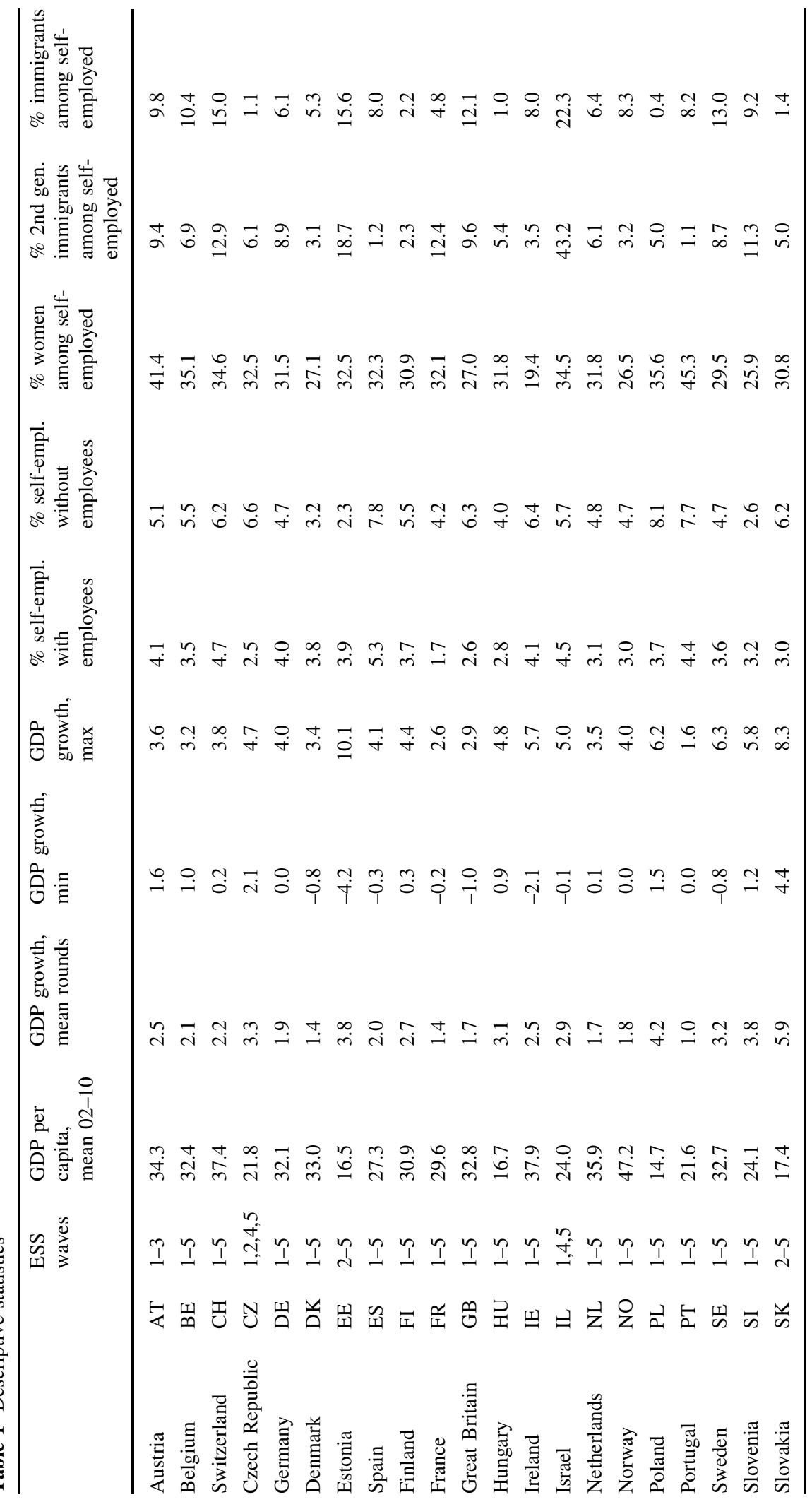


is represented by 'ISCED 0-1', comprising respondents who have completed only primary education or less. The highest educational attainment is represented by 'ISCED 5-6', comprising respondents who have completed a tertiary education.

\section{Methods}

The structure of the ESS data consists of variables at three different levels: the individual level, the countryyear level and the country level. In order to accommodate this three-level structure-where individuals (level 1) are nested within country-years (level 2), which in turn are nested within countries (level 3) multilevel modelling is applied. Multilevel analysis (MLA) is useful when exploring how information and data measured at different levels are connected, i.e. when dealing with variables that belong to different hierarchical levels (Hox 2010; Steenbergen and Jones 2002). Multilevel models are basically extensions of linear regression models; they provide accurate estimates of uncertainty and statistical significance and allow us to simultaneously explore the relationship between individual-level characteristics (microlevel) and contextual-level characteristics (macrolevel) in relation to our dependent variable measured at the individual level. In our case, this means that we can simultaneously investigate the effect of both individual-level variables (such as our main variable 'type of employment') and contextual-level variables (such as 'GDP per capita' and 'GDP growth') on the respondents' SWB. Multilevel analysis also allows for the investigation of cross-level interaction effects, i.e. to what extent individuals are differentially influenced by a specific characteristic of the context. This is of particular importance for this study since one of the research questions specifically deals with the question of whether the self-employed are more sensitive to macroeconomic conditions when compared to regular employees.

\section{Results}

As previously mentioned, the aim of this article is to further investigate the relationship between self-employment and subjective well-being by bringing the macroeconomy, gender and immigrant status into the analyses. Four initial research questions were stated: (1) do self-employed individuals experience a higher or a lower level of SWB than that experienced by employees and supervisors? (2) Are there differences between the self-employed with and without employees regarding their levels of SWB? (3) Are macroeconomic conditions more or less important for the SWB of self-employed people compared with supervisors and employees? (4) Does the relationship between employment type and life satisfaction vary according to gender and immigrant status?

The first three research questions are investigated in Table 2 which presents multilevel models of the relationship between individual factors, contextual factors and life satisfaction, respectively. Model 1 presents crude bivariate relationships between individual-level covariates and life satisfaction; Model 2 simultaneously includes all individual-level covariates; Model 3 adds our two contextual-level variables (mean GDP per capita and GDP growth); and Model 4 adds an interaction term between type of employment and GDP growth. An 'empty' model is presented at the bottom of Table 2 and serves as a baseline which allows for an assessment of what the additional variables explain in relation to the variation at our three different levels - the individual level, the country level and the country-year level.

Starting with research questions 1 and 2, we can see in the crude Model 1 that the self-employed with employees appear to be the group that is best off in terms of life satisfaction. This group is followed by supervisors, while those self-employed people without employees do not appear to be significantly better off than employees. When individual-level covariates are introduced, the difference between the self-employed without employees and employees in terms of life satisfaction, however, becomes significant. This is mainly a result of entering the level of education into the model, where the self-employed without employees have somewhat higher life satisfaction than what might be expected given their educational level. By changing the reference category in the models, we also find that the difference between the two groups of selfemployed is statistically significant. The relationships from Model 2 further hold when the two contextuallevel variables are introduced in Model 3. The conclusions that can be drawn in relation to the first two research questions are thus: (1) yes-the selfemployed do have higher levels of life satisfaction 
Table 2 Relationship between type of employment, macroeconomy and subjective well-being

\begin{tabular}{|c|c|c|c|c|c|c|c|c|}
\hline & \multicolumn{2}{|l|}{ M1 } & \multicolumn{2}{|l|}{ M2 } & \multicolumn{2}{|l|}{ M3 } & \multicolumn{2}{|l|}{ M4 } \\
\hline & $b$ & SE & $b$ & SE & $b$ & SE & $b$ & SE \\
\hline ESS wave (1-5) & 0.02 & 0.02 & 0.01 & 0.02 & 0.05 & 0.01 & 0.05 & 0.01 \\
\hline \multicolumn{9}{|l|}{ Gender (Ref.: women) } \\
\hline Men & -0.04 & 0.01 & -0.05 & 0.01 & -0.06 & 0.01 & -0.06 & 0.01 \\
\hline \multicolumn{9}{|l|}{ Age (Ref.: 55-64 years) } \\
\hline $16-24$ years & 0.28 & 0.03 & 0.33 & 0.03 & 0.29 & 0.03 & 0.29 & 0.03 \\
\hline 25-39 years & 0.20 & 0.02 & 0.16 & 0.02 & 0.13 & 0.02 & 0.13 & 0.02 \\
\hline $40-54$ years & -0.02 & 0.02 & -0.04 & 0.02 & -0.06 & 0.02 & -0.06 & 0.02 \\
\hline \multicolumn{9}{|l|}{ Education (Ref.: ISCED 5-6) } \\
\hline ISCED $0-1$ & -0.61 & 0.03 & -0.50 & 0.03 & -0.45 & 0.03 & -0.45 & 0.03 \\
\hline ISCED 2 & -0.43 & 0.02 & -0.36 & 0.02 & -0.33 & 0.02 & -0.33 & 0.02 \\
\hline ISCED 3 & -0.29 & 0.01 & -0.27 & 0.02 & -0.26 & 0.02 & -0.26 & 0.02 \\
\hline ISCED 4 & -0.21 & 0.03 & -0.20 & 0.03 & -0.19 & 0.03 & -0.19 & 0.03 \\
\hline \multicolumn{9}{|l|}{ Immigrant status (Ref.: immigrant) } \\
\hline Native & 0.31 & 0.02 & $\mathbf{0 . 3 2}$ & 0.02 & $\mathbf{0 . 3 3}$ & 0.02 & $\mathbf{0 . 3 3}$ & 0.02 \\
\hline Second-gen. immigrant & 0.20 & 0.03 & 0.19 & 0.03 & 0.20 & 0.03 & 0.20 & 0.03 \\
\hline \multicolumn{9}{|l|}{ Employment type (Ref.: employed) } \\
\hline Self-employed w. employees & 0.31 & 0.03 & 0.34 & 0.03 & 0.32 & 0.03 & 0.16 & 0.04 \\
\hline Self-employed no employees & 0.02 & 0.02 & 0.07 & 0.02 & 0.08 & 0.02 & 0.01 & 0.04 \\
\hline Supervisors & 0.26 & 0.01 & 0.22 & 0.02 & 0.22 & 0.02 & 0.19 & 0.02 \\
\hline Mean GDP per capita & & & & & 0.06 & 0.01 & 0.06 & 0.01 \\
\hline GDP growth & & & & & 0.04 & 0.01 & $\mathbf{0 . 0 3}$ & 0.01 \\
\hline Self-empl w. empl.*GDP growth & & & & & & & 0.07 & 0.01 \\
\hline Self-empl no empl.*GDP growth & & & & & & & 0.02 & 0.01 \\
\hline Supervisors*GDP growth & & & & & & & 0.01 & 0.01 \\
\hline Employed*GDP growth & & & & & & & 0.00 & 0.00 \\
\hline Intercept & & & 6.76 & 0.20 & 4.90 & 0.44 & 4.92 & 0.44 \\
\hline Residual & & & 3.56 & 0.02 & 3.44 & 0.02 & 3.44 & 0.02 \\
\hline Country & & & 0.75 & 0.23 & 0.29 & 0.10 & 0.29 & 0.10 \\
\hline Country-year & & & 0.07 & 0.01 & 0.05 & 0.01 & 0.05 & 0.01 \\
\hline-2 restricted log-likelihood & & & $369,674.8$ & & $340,213.2$ & & $340,207.6$ & \\
\hline \multicolumn{9}{|l|}{ Baseline model } \\
\hline Residual & & & 3.66 & 0.02 & & & & \\
\hline Country variance & & & 0.79 & 0.25 & & & & \\
\hline Country-year variance & & & 0.07 & 0.01 & & & & \\
\hline
\end{tabular}

Dependent variable: life satisfaction (0-10)

Cell entries are unstandardized regression coefficients and standard errors. Estimates in bold: $p<0.05$

than employees, although supervisors also have comparable levels; (2) yes-there are differences between the self-employed with and without employees: the former is the group that without question has the highest level of life satisfaction, while those selfemployed who have no employees are substantially less well off in this respect.
Our third research question related to the importance of macroeconomic conditions for the relationship between self-employment and life satisfaction. Looking at Model 3, we saw that there was no substantial impact on the relationship between selfemployment and life satisfaction by simply introducing GDP per capita and GDP growth. Looking in 
Model 3 at the relationships between these variables and life satisfaction, we can, however, see that these are both significantly and positively related to life satisfaction. Comparing the variance components between Model 2 and Model 3, we can also see that country-level variance is more than halved and that country-year variance is also reduced. This suggests that these variables help to explain a substantial proportion of the variance between countries and over time. In Model 4, the sensitivity of the relationship between self-employment and life satisfaction to macroeconomic conditions is investigated using cross-level interaction terms. The interaction terms in Model 4 between type of employment and GDP growth turn out to be significant. Compared with employees, both groups of self-employed have significant positive interactions with GDP growth, indicating that the benefits of self-employment are significantly greater under positive macroeconomic conditions. This is particularly true for the selfemployed with employees as they receive a substantial booster effect on life satisfaction from economic growth.

After concluding that self-employment in general is beneficial for life satisfaction (while acknowledging the differences between the self-employed with and without employees, as well as variations related to macroeconomic conditions), we now turn to our fourth research question: does the relationship between employment type and life satisfaction vary according to gender and immigrant status? This is investigated in Tables 3 and 4 where the relationship between type of employment and life satisfaction is firstly analysed separately for men and women (Table 3 ) and secondly for different immigrant status groups (Table 4), with controls for all individual- and contextual-level covariates.

The findings in Table 3 indicate that the relationship between the self-employed with employees and life satisfaction is very similar for men and women. In contrast, the relationship between the self-employed without employees and life satisfaction appears to be gendered. The correlation is lower than in the pooled analysis and non-significant among men. For women, on the other hand, the correlation is statistically significant and stronger than in the pooled analysis, suggesting that the overall positive association for self-employed individuals without employees found in Table 2 is mainly related to women.

Looking at the immigrant status groups, Table 4 shows that there are substantial differences between them. As shown in Table 2, the self-employed, and in particular those with employees, are more satisfied with life than employees. There are, however, smaller differences between the self-employed and employees among native respondents than among the immigrant groups. Among first- and second-generation immigrants, selfemployment with employees is particularly beneficial. Self-employment without employees is in turn associated with particularly high levels of life satisfaction among first-generation immigrants. The correlation between the self-employed without employees and life satisfaction is four times as large among first-generation immigrants than among native-born respondents.

The conclusions that can be drawn regarding research question 4 are that there does indeed appear to be differences in the relationship between type of employment and life satisfaction depending on gender
Table 3 Relationship between employment type and subjective well-being by gender

Dependent variable: life satisfaction (0-10)

Cell entries are unstandardized regression coefficients and standard errors. Controls from Model 3 in Table 2 included in models. Estimates in bold: $p<0.05$

\begin{tabular}{|c|c|c|c|c|}
\hline & \multicolumn{2}{|l|}{ Men } & \multicolumn{2}{|l|}{ Women } \\
\hline & $b$ & SE & & $\mathrm{SE}$ \\
\hline \multicolumn{5}{|c|}{ Employment type (Ref.: employed) } \\
\hline Self-employed w. employees & 0.33 & 0.03 & 0.32 & 0.06 \\
\hline Self-employed no employees & 0.05 & 0.03 & 0.12 & 0.04 \\
\hline Supervisors & 0.26 & 0.02 & 0.17 & 0.02 \\
\hline Intercept & 4.78 & 0.42 & 4.90 & 0.46 \\
\hline Residual & 3.39 & 0.02 & 3.49 & 0.03 \\
\hline Country & 0.26 & 0.09 & 0.31 & 0.10 \\
\hline Country-year & 0.04 & 0.01 & 0.05 & 0.01 \\
\hline-2 restricted log-likelihood & $180,473.5$ & & $159,899.8$ & \\
\hline
\end{tabular}


Table 4 Relationship between employment type and subjective well-being by immigrant status

Dependent variable: life satisfaction (0-10)

Cell entries are unstandardized regression coefficients and standard errors. Controls from Model 3 in Table 2 included. Estimates in bold: $p<0.05$

\begin{tabular}{|c|c|c|c|c|c|c|c|}
\hline & \multicolumn{3}{|c|}{ Natives } & \multicolumn{2}{|c|}{ Second-gen. immigrants } & \multicolumn{2}{|c|}{ Immigrants } \\
\hline & $b$ & & SE & $b$ & SE & $b$ & SE \\
\hline \multicolumn{8}{|c|}{ Employment type (Ref.: employed) } \\
\hline Self-employed w. employees & & 0.29 & 0.03 & 0.43 & 0.12 & 0.48 & 0.11 \\
\hline Self-employed no employees & & 0.06 & 0.03 & 0.09 & 0.10 & 0.24 & 0.10 \\
\hline Supervisors & & 0.21 & 0.02 & 0.25 & 0.06 & 0.24 & 0.06 \\
\hline Intercept & & 5.26 & 0.45 & 4.93 & 0.46 & 5.06 & 0.44 \\
\hline Residual & & 3.31 & 0.02 & 3.96 & 0.07 & 4.16 & 0.07 \\
\hline Country & & 0.31 & 0.10 & 0.28 & 0.10 & 0.21 & 0.08 \\
\hline Country-year & & 0.05 & 0.01 & 0.02 & 0.01 & 0.03 & 0.02 \\
\hline-2 restricted log-likelihood & \multicolumn{3}{|c|}{$282,833.8$} & \multicolumn{2}{|l|}{$27,228.4$} & \multicolumn{2}{|l|}{$29,960.4$} \\
\hline
\end{tabular}

and immigrant status. Self-employment without employees is particularly beneficial for women and first-generation immigrants. For self-employment with employees, there were no gender differences, but the positive relationship is particularly strong among both first- and second-generation immigrants.

\section{Conclusions and discussion}

Research has shown that self-employment is important for regional and national economic development, not least because of the large number of jobs it provides (Davidsson 2005). Subjective well-being among the self-employed is an area that is also undoubtedly important, yet the variations between and within different groups of self-employed remain inadequately studied (Stephan and Roesler 2010; Toivanen et al. 2014). In this study, a large European data set was used to analyse life satisfaction among different groups of self-employed in comparison with employees and supervisors. The main aim was to increase our knowledge about self-employed individuals' life satisfaction by considering macroeconomic conditions, gender and immigrant status.

The results show that the self-employed generally have a higher level of life satisfaction than those who are employed, but there are also clear differences between different groups of the self-employed. Particularly, self-employed individuals who employ others have a higher level of life satisfaction than regular employees, while self-employed without employees are substantially less well off in this respect. Economic growth is of more importance for the level of life satisfaction among the self-employed than among employees. This is particularly true for the self-employed with employees whose sense of life satisfaction is significantly boosted by strong economic growth.

The findings also indicate that the relationship between self-employment with employees and life satisfaction is very similar for men and women. In marked contrast, however, the relationship between self-employment without employees and life satisfaction does appear to be gendered, with only selfemployed women experiencing a higher level of life satisfaction in comparison with employees, while no such difference is found among men. Looking at immigrant status groups, the results show that there are differences between groups when it comes to the level of life satisfaction. Among first- and second-generation immigrants, self-employment with employees is particularly beneficial. Self-employment without employees is in turn associated with particularly high levels of life satisfaction among first-generation immigrants compared with second-generation immigrants and natives.

Strong indications of a high level of life satisfaction among the self-employed in general are in line with the results from a majority of earlier studies (e.g. Amoros and Bosma 2013; Andersson 2008; Benz and Frey 2008; Binder and Coad 2013; Blanchflower and Oswald 2004; Stephan and Roesler 2010). Some commentators (e.g. Andersson 2008; Coad and Binder 2014; Stephan and Roesler 2010) have suggested that the main explanation for this general finding is that the self-employed have greater autonomy and regard their work as more interesting. Following Stephan and 
Roesler, one could argue that self-employment is a prototype of an 'active job' with high job demands but also - and crucially — high job control. Based on the active job hypothesis, one could confidently expect the self-employed to experience better health outcomes compared with employees.

Another explanation for differences in well-being between the self-employed and employees is-surprisingly - often overlooked in the literature, namely the tendency for comparatively healthy individuals to opt for self-employment (Hilbrecht and Lero 2014). Moving into self-employment may be associated with an individual's positive health status for several reasons. Firstly, ill health decreases the ability to focus on business opportunities. Secondly, ill health may limit access to crucial start-up financing. Thirdly, self-employment is a financially less attractive option compared with wage work for less healthy individuals. Fourthly, less healthy individuals may prefer to stay in wage work because it would be more expensive or impossible to get insurance while self-employed. These arguments all support the assertion that it tends to be healthier individuals who choose to become selfemployed. Nonetheless, it should be stressed that because those with health problems may experience difficulties in finding suitable wage work, they could be pushed into seeking self-employment out of necessity (Verheul et al. 2010).

Our result suggesting that self-employment with employees seems to be more beneficial than selfemployment without employees is interesting, although some previous studies point at better health-related outcomes among the self-employed with employees (Benavides et al. 2000; Toivanen et al. 2014). There are several possible explanations for this result. As already mentioned, self-employed individuals without employees are often personally responsible for all financial matters, including liability for possible debts in cases of bankruptcy (Toivanen et al. 2014). It seems possible that they are exposed to greater stresses than the self-employed with employees because they alone face the pressure of promoting the business, dealing with paperwork, financial responsibility, personal risk and role conflict (Grant and Ferris 2015). It is also possible that the selfemployed without employees more often are necessity-driven self-employed (that is, self-employed who are pushed into starting a business because they have no other options for work) and that they therefore have considerably lower rates of subjective well-being compared to opportunity-driven entrepreneurs (Amoros and Bosma 2013; Binder and Coad 2013).

Another possible explanation for this outcome relates to the role of employees. Self-employed people with employees can assimilate all of the beneficial aspects of being self-employed while at the same time making valuable social contacts with their employees. This explanation is supported by the fact that supervisors, another group that has a large decision space and access to work colleagues, report a similar high level of life satisfaction as self-employed with employees. An explanation for the result showing that self-employment without employees is positively related to life satisfaction only among women may be connected to this. Women do in general have larger social networks outside of work, and this can compensate for the low number of personal contacts that solo entrepreneurship often means. According to several researchers, social relations are of particular importance in today's working environment and high levels of social support have shown significant associations with different objective and subjective health outcomes (Sundin 2009). Furthermore, the positive relationship between self-employment without employees and life satisfaction found among women can be related to previous findings suggesting that selfemployed women more often than self-employed men are motivated by family and lifestyle concerns. This gendered difference in the reasons for starting a business might well explain why we find a significantly positive relationship between self-employment without employees and subjective well-being (as opposed to job satisfaction) among women but not among men.

The strong positive association between self-employment and life satisfaction among immigrants may be related to the fact that the beneficial aspects of being self-employed are of more importance for immigrants than natives. To be strongly committed to the job and have higher levels of autonomy may be of greater value within groups which overall have weaker positions on the labour market and in society as a whole. The differences found within the group of immigrants thus suggest that despite that many immigrants might be pushed into self-employment for want of better options on the labour market selfemployment is nevertheless associated with higher levels of subjective well-being than regular 
employment within this group. The assumption that life satisfaction should be especially high among the self-employed compared with among regular employees in a growing economy is supported by the results from this study. A highly plausible explanation is that it is easier to have a high level of control over one's own job and income, and for the jobs and incomes of one's employees, in a growing economy than in a recession. In turn, this means that it is easier to be satisfied and happy when economic conditions are good than when they are bad, an explanation that is supported by other research (Amoros and Bosma 2013; Carree and Verheul 2012).

As in all scientific studies, there are both weak and strong sides to this research. Analysing statistics generated from comparative data is not entirely unproblematic, and consequently, the results should be interpreted with some caution. The framing of survey questions is context dependent, meaning that certain questions may be understood and interpreted differently in different cultural and national contexts. Another problem is that the study is cross-sectional which means that it is difficult to judge whether the associations found are causal, and if they are, in what direction. It might well be that personality traits affect the selection into self-employment and that more satisfied and optimistic individuals are more likely to become self-employed (Naudé et al. 2014; Rauch and Frese 2007). Measuring subjective well-being with a single item might also be considered a limitation, but when analysing multiple waves of the ESS data the use of a single-item measure is the only available option. Previous research furthermore suggests that the single item works satisfactorily when attempting to measure the cognitive component of subjective well-being (Diener et al. 2013; Fors and Kulin 2015). The data set also imposes some limitations in terms of other potentially important predictors of life satisfaction such as personality traits which we cannot take into account. Industry sector is another potentially important factor related to self-employment that we cannot take into account due to data limitations. Furthermore, additional information about various motives and circumstances related to self-employment would have made it possible to explicitly study differences in life satisfaction within the group of self-employed based on, for example, the distinction between necessity and opportunity self-employed. Against these weaknesses must be set the positive fact that the results of this study are based on a large harmonized and panEuropean sample. The large number of respondents makes it possible to study different subgroups, such as the self-employed with and without employees. The fact that the results are based on nationally representative samples from a large number of European countries means that it is possible to generalize the result to the level of the continent and to compare parts of Europe that have very different economic conditions. Accordingly, the results are valid for a large part of the European population.

\subsection{Implications}

The results of this study confirm the importance of considering differences between groups of the selfemployed when developing policies and measures for increased life satisfaction and other health-related outcomes at societal, organizational and individual levels. Policy makers need to consider the significant differences that this study has found between the selfemployed with and without employees, self-employed men and women and different immigrant groups. When promoting self-employment, training programmes should address different kinds of demands and conditions for helping new and prospective selfemployed people to realistically address the conditions associated with starting up their business and to identify strategies for dealing with possible negative factors relevant for the individual. Further research in this field is undoubtedly necessary and should seek to extend the results of this work by uncovering additional explanations for the differences in the subjective well-being found among the self-employed. The possibilities for research into the nature of selfselection by the self-employed and the contextual impact on health-related outcomes among the selfemployed would seem to be potentially promising in this regard.

\section{References}

Aldrich, H. E., \& Renzulli, L. A. (1981). Passing on privilege: Resources provided by self-employed parents to their selfemployed children. In K. Leicht (Ed.), Research in social stratification and mobility. Greenwich, CT: JAI Press.

Amoros, J. E., \& Bosma, N. (2013). Global Entrepreneurship Monitor 2013 Global Report. 
Andersson, P. (2008). Happiness and health: Well-being among the self-employed. The Journal of Socio-Economics, 37, 213-236. doi:10.1016/j.socec.2007.03.003.

Andersson, L., \& Hammarstedt, M. (2012). Intergenerational transmissions in immigrant self-employment: Evidence from three generations. Small Business Economics, 34, 261-276. doi:10.1007/s11187-008-9117-y.

Benavides, F. G., Benach, J., Diez-Roux, A. V., \& Roman, C. (2000). How do types of employment relate to health indicators? Findings from the second European survey of working conditions. Journal Epidemiology Community Health, 54, 494-501. doi:10.1136/jech.54.7.494.

Benz, M., \& Frey, B. S. (2004). Being independent raises happiness at work. Swedish Economic Policy Review, 12, 97-138.

Benz, M., \& Frey, B. S. (2008). Being independent is a great thing: Subjective evaluations of self-employment and hierarchy. Economica, 75(298), 362-383. doi:10.1111/j. 1468-0335.2007.00594.x.

Bernin, P. (2002). Managers' working conditions stress and health (Doctoral thesis). Karolinska Institutet, Stockholm, Sweden.

Binder, M., \& Coad, A. (2013). Life satisfaction and self-employment: A matching approach. Small Business Economics, 40, 1009-1033. doi:10.1007/s11187-011-9413-9.

Blanchflower, D. G. (2004). Self-employment: More may not be better. Swedish Economic Policy Review, 11(2), 15-73.

Blanchflower, D. G., \& Oswald, A. (1998). What makes an entrepreneur? Journal of Labor Economics, 16, 26-60.

Blanchflower, D. G., \& Oswald, A. (2004). Well-being over time in Britain and the USA. Journal of Public Economics, 88, 1359-1386. doi:10.1016/S0047-2727(02)00168-8.

Block, J., \& Koellinger, P. (2009). I can't get no satisfactionnecessity entrepreneurship and procedural utility. Kyklos, 62(2), 191-209. doi:10.1111/j.1467-6435.2009.00431.x.

Carree, M. A., \& Verheul, I. (2012). What makes entrepreneurs happy? Determinants of satisfaction among founders. Journal of Happiness Studies, 13, 371-387. doi:10.1007/ s10902-011-9269-3.

Coad, A., \& Binder, M. (2014). Causal linkages between work and life satisfaction and their determinants in a structural VAR approach. Economics Letters, 124(2), 263-268. doi:10.1016/j.econlet.2014.05.021.

Dana, L. P. (1997). The origins of self-employment in Ethnocultural communities: Distinguishing between orthodox entrepreneurship and reactionary enterprise. Canadian Journal of Administrative Sciences/Revue Canadienne des Sciences de l'Administration, 14(1), 52-68. doi:10.1111/j. 1936-4490.1997.tb00118.x.

Davidsson, P. (2005). Researching entrepreneurship. New York: Springer.

Dawson, C. J., Henley, A., \& Latreille, P. L. (2009). Why do individuals choose self-employment? IZA discussion paper no. 3974. http://ssrn.com/abstract=1336091.

Diener, E. (1984). Subjective well-being. Psychological Bulletin, 95, 542-575.

Diener, E. (2000). Subjective well-being: The science of happiness, and a proposal for a national index. American Psychologist, 55, 34-43.

Diener, E., Inglehart, R., \& Tay, L. (2013). Theory and validity of life satisfaction scales. Social Indicators Research, 112(3), 497-527. doi:10.1007/s11205-012-0076-y.
Diener, E., \& Seligman, M. E. P. (2004). Beyond money: Toward an economy of well-being. Psychological Science in the Public Interest, 5, 1-31.

Diener, E., Suh, E. M., Lucas, R. E., \& Smith, H. L. (1999). Subjective well-being: Three decades of progress. Psychological Bulletin, 125(2), 276-302.

Dolinsky, A. L., \& Caputo, R. K. (2003). Health and female selfemployment. Journal of Small Business Management, 41(3), 233-241. doi:10.1111/1540-627X.00079.

Eden, D. (1975). Organizational membership vs. self-employment: Another blow to the american dream. Organizational Behavior and Human Performance, 11(1), 79-94.

Eurofound. (2012). Third European quality of life surveyquality of life in Europe: Impacts of the crisis. Luxembourg: Publications Office of the European Union.

European Commission. (2004). Action plan: The European agenda for entrepreneurship. http://europa.eu.int/comm/ enterprise/entrepreneurship/action_plan

Fölster, S. (2000). Do entrepreneurs create jobs? Small Business Economics, 14(2), 137-148. doi:10.1023/A:1008141516 160.

Fors, F., \& Kulin, J. (2015). Bringing affect back in: Measuring and comparing subjective well-being across countries. Social Indicators Research. doi:10.1007/s11205-015-0947-0.

Fuchs-Schundeln, N. (2009). On preferences for being selfemployed. Journal of Economic Behavior \& Organization, 71, 162-171. doi:10.1016/j.jebo.2009.03.024.

Grant, S., \& Ferris, K. (2015). Identifying sources of occupational stress in entrepreneurs for measurement. International Journal of Entrepreneurial Venturing, 4(4), 351-373. doi:10.1504/IJEV.2012.049828.

Gunnarsson, K., Vingård, E., \& Josephson, M. (2007). Selfrated health and working conditions of small-scale enterprisers in Sweden. Industrial Health, 45, 775-780. doi:10. 2486/indhealth.45.775.

Hackman, R. J., \& Oldham, G. R. (1975). Development of the job diagnostic survey. Journal of Applied Psychology, 60, 159-170.

Harte, S. (1996, July 29). Women who work it out. Atlanta Journal Constitution, C1.

Henrekson, M., \& Stenkula, M. (2009). Entrepreneurship and public policy. Stockholm: Research Institute of Industrial Economics.

Hilbrecht, M., \& Lero, D. S. (2014). Self-employment and family life: Constructing work-life balance when you're 'always on'. Community, Work \& Family, 17(1), 20-42. doi:10.1080/13668803.2013.862214.

Hox, J. (2010). Multilevel methods: Techniques and analysis. London: Routledge.

Hundley, G. (2001). Why and when are the self-employed more satisfied with their work? Industrial Relations, 40, 293-316. doi:10.1111/0019-8676.00209.

Irastorza, N., \& Peña, I. (2014). Earnings of immigrants: Does entrepreneurship matter? The Journal of Entrepreneurship, 23(1), 35-56. doi:10.1177/0971355713513352.

Jamal, M. (1997). Job stress, satisfaction and mental health: An empirical examination of self-employed and non self-employed Canadians. Journal of Small Business Management, 35(4), 48-57.

Johansson Sevä, I., \& Öun, I. (2015). Self-employment as a strategy for dealing with the competing demands of work 
and family? The importance of family/lifestyle motives. Gender, Work and Organization, 22, 256-272. doi:10. 1111/gwao.12076.

Jovanovic, V. (2011). Personality and subjective well-being: One neglected model of personality and two forgotten aspects of subjective well-being. Personality and Individual Differences, 50, 631-635. doi:10.1016/j.paid.2010.12. 008 .

Lange, T. (2012). Job satisfaction and self-employment: Autonomy or personality? Small Business Economics, 38, 165-177. doi:10.1007/s11187-009-9249-8.

Loscocco, K. A., \& Roschelle, A. R. (1991). Influences on the quality of work and nonwork life: Two decades in review. Journal of Vocational Behavior, 39, 185-225. doi:10.1016/ 0001-8791(91)90009-B.

Mandel, M. J. (1996). The high risk society: Peril and promise in the new economy. New York: Times Business.

Marler, J. H., \& Moen, P. (2005). Alternative employment arrangements: A gender perspective. Sex Roles, 52(5-6), 337-349. doi:10.1007/s11199-005-2677-2.

Müller, W., \& Arum, R. (2004). Self-employment dynamics in advanced economies. In R. Arum \& W. Müller (Eds.), The reemergence of self-employment: A comparative study of self-employment dynamics and social inequality (pp. 1-35). Princeton: Princeton University Press.

Naudé, W., Amorós, J. E., \& Cristi, O. (2014). "Surfeiting, the appetite may sicken": entrepreneurship and happiness. Small Business Economics, 42(3), 523-540. doi:10.1007/ s11187-013-9492-x.

Ndofor, H. A., \& Priem, R. L. (2011). Immigrant entrepreneurs, the ethnic enclave strategy, and venture performance. Journal of Management, 37(3), 790-818. doi:10.1177/ 0149206309345020.

Nordenmark, M., Vinberg, S., \& Strandh, M. (2012). Job control and demands, work-life balance and wellbeing among selfemployed men and women in Europe. Vulnerable Groups \& Inclusion, doi:10.3402/vgi.v3i0.18896.

Ochsen, C. (2011). Subjective well-being and aggregate unemployment: Further evidence. Scottish Journal of Political Economy, 58(5), 634-655. doi:10.1111/j.14679485.2011.00562.x.

Parasuraman, S., \& Simmers, C. A. (2001). Type of employment, work-family conflict and well-being: A comparative study. Journal of Organizational Behavior, 22, 551-568. doi:10.1002/job.102.

Parslow, R. A., Jorm, A. F., Christensen, H., Rodgers, B., Strazdins, L., \& D'Souza, R. M. (2004). The associations between work stress and mental health: A comparison of organizationally employed and self-employed workers. Work \& Stress, 18(3), 231-244. doi:10.1080/147497304 12331318649.

Rau, R., Hoffmann, K., Metz, U., Richter, P. G., Roesler, U., \& Stephan, U. (2008). Gesundheitsrisiken bei Unternehmern
[Health risks of entrepreneurs]. Zeitschrift für Arbeits- und Organisationspsychologie, 52, 115-125. doi:10.1026/ 0932-4089.52.3.115.

Rauch, A., \& Frese, M. (2007). Let's put the person back into entrepreneurship research: A meta-analysis on the relationship between business owners' personality traits, business creation, and success. European Journal of Work and Organizational Psychology, 16(4), 353-385. doi:10. 1080/13594320701595438.

Rogers, N. E. (1998). The role of marital status, family composition, role commitment, family support of career and role conflict in women business owners' success (Doctoral thesis). University of Cincinatti, Cincinnati, $\mathrm{OH}$.

Steenbergen, M. R., \& Jones, B. S. (2002). Modeling multilevel data structures. American Journal of Political Science, 46(1), 218-237. doi:10.2307/3088424.

Stephan, U., \& Roesler, U. (2010). Health of entrepreneurs vs. employees in a national representative sample. Journal of Occupational and Organizational Psychology, 83(3), 717-738. doi:10.1348/096317909X472067.

Sundin, L. (2009). Work-related social support, job demands and burnout: studies of Swedish workers, predominantly employed in health care (Thesis). Stockholm, Sweden: Karolinska Institutet.

Tella, R. D., MacCulloch, R. J., \& Oswald, A. J. (2003). The macroeconomics of happiness. The Review of Economics and Statistics, 85(4), 809-827. doi:10.1162/003465303 772815745.

Toivanen, S., Mellner, C., \& Vinberg, S. (2014). Self-employed persons in Sweden-mortality differentials by industrial sector and enterprise legal form: A five year follow-up study. American Journal of Industrial Medicine,. doi:10. 1002/ajim.22387.

Veenhoven, R. (2004). Subjective measures of well-being (No. 2004/07). WIDER Discussion Papers//World Institute for Development Economics (UNU-WIDER). http://hdl. handle.net/10419/52848

Verheul, I., Thurik, A. R., Hessels, J., \& Van der Zwan, P. W. (2010). Factors influencing the entrepreneurial engagement of opportunity and necessity entrepreneurs. Research Reports EIM Zoetermeer.

Verheul, I., \& Wennekers, S. (2002). Entrepreneurship: Determinants and policy in a European-US comparison. Boston: Kluwer.

Weiss, A., Bates, T. C., \& Luciano, M. (2008). Happiness is a personal(ity) thing: The genetics of personality and wellbeing in a representative sample. Psychological Science, 19(3), 205-210. doi:10.1111/j.1467-9280.2008.02068.x.

Welsch, H., \& Bonn, U. (2008). Economic convergence and life satisfaction in the European Union. Journal of SocioEconomics., 37(3), 1153-1167. doi:10.1016/j.socec.2006. 12.072 . 